\title{
Risk Assessment Model and Applied Research on Municipal PPP Projects
}

\author{
Liping WANG \\ School of Renewable Energy \\ North China Electric Power University \\ Beijing, China \\ e-mail: liping_w@163.com \\ Pei ZHANG \\ School of Renewable Energy \\ North China Electric Power University \\ Beijing, China \\ e-mail: 517815037@qq.com
}

\author{
$\mathrm{Pu}$ ZHANG \\ School of Economic and Management \\ North China Electric Power University \\ Beijing, China \\ e-mail: zhpu17@163.com \\ Yawei ZHAO \\ School of Renewable Energy \\ North China Electric Power University \\ Beijing, China \\ e-mail:731617163@qq.com
}

\author{
Yuan MA \\ School of Renewable Energy \\ North China Electric Power University \\ Beijing, China \\ e-mail: 784960844@qq.com
}

\begin{abstract}
Since PPP (Public Private Partnership) project is playing an increasingly important role in the investment and construction of China's municipal works, considering features like wide evaluation range and multiple risk resources while conducting risk evaluation of PPP Project, this paper establishes risk evaluation model by drawing on the theory of relative risk model and introduces the concept of variable weight to achieve further reasonableness. The results show that this model is very effective for quantitative risk evaluation of municipal PPP Project and can be a reference for studies and practice of risk evaluation and management of this project.
\end{abstract}

Keywords-public private partnership; municipal works; relative risk model; risk assessment

\section{INTRODUCTION}

As a public service supply mechanism distinct from traditional mode, PPP has become a brand new one with fastest growth in infrastructure and public service over the past few decades. However, it should be noted that PPP Project features long period, vast investment and high risks owing to the complexity of its cooperative model, compared with other projects. Practical experience tells that some projects acquire extremely high risks [1]. In May, 2015, when the Treasury issued the Notice on the Guidance on Promoting Public and Private Partnership Model in the Field of Public Service, China's PPP Project has entered a stage of rapid development. By the end of March, 2016, the number of projects in the project library of National PPP Integrated Information Platform has reached 7,721 with a total investment of 8,780 billion yuan, which includes 2,704 municipal ones with the investment of 2,380 billion yuan, becoming the industry with the most projects and second largest investment. Owing to distinctive economic, financial and policy environment, China's municipal PPP Project possesses unique definition and connotation. Thus, the better way of quantifying PPP Project's risks becomes the key to improve its project efficiency. So conducting risk evaluation of the municipal PPP Project has important research significance.

When it comes to the risk assessment of PPP Project, studies done by A. Akintoye, M. Macleod, J. Lyons and others show that qualitative analysis of risks based on expert experience, judgement and subjective evaluation is the common method of risk assessment [2, 3]. As for qualitative analysis, Monte Carlo simulation and sensitivity analysis ${ }^{[4]}$ are the commonly used risk assessment methods for PPP Project in previous studies. But since sufficient numerical data is required for those two methods, they can't be applied to PPP Project's risk assessment as widely as to its financial evaluation and related risk assessment.

Hence, previous risk studies of PPP dominated by qualitative analysis can merely provide the decision makers analyzing project risk with suggestions on the priority order of dealing with risks. This paper takes relative risk model as the core, and introduces multi-index test, analytic hierarchy process and expert judgment method to enhance the objectivity and university of evaluation method. This paper also seeks to propose an assessment method which combines qualitative and quantitative analysis. Meanwhile, considering the insensitivity of relative risk model towards the equilibrium degree of combination changes, the concept of variable weight is introduced to improve this model. 


\section{MUNICIPAL PPP's RISK ASSESSMENT MODEL}

\section{A. Relative Risk Model}

Relative Risk Model (RRM) is a regional composite pressure risk assessment method put forward by Landis W.G. and Wiegers J.A. in 1997. In this model, hierarchical system is adopted to evaluate various risk sources and habitats of assessment units. Analysis of interactions among each factor needing assessment can lead to a comprehensive method of regional risk assessment, thereby achieving quantitative assessment [5]. This model can effectively avoid the excessive amount of risk factors and properly handle the uncertainty in risk assessment process.

\section{B. Variable Weight Theory}

The concept of various is first put forward by Professor Wang Peizhuang. It stresses that factor's weight should change in accordance with the change of its state value to remedy the deviation [6,7] caused by the decision of constant weight. Based on the theory of factor space, Professor Li Hongxing gives the axiomatic definitions of variable weight and state variable weight vector and establishes a set of axiomatic system [8] for comprehensive decision of variable weight.

a. The definition of constant weight set

If within the function, $\omega_{\mathrm{i}} \in[0,1](i=1,2, \cdots, \mathrm{n})$, $\& \sum_{\mathrm{j}=1}^{\mathrm{m}} \omega_{\mathrm{i}}=1$, the formula is called the constant weight synthetic function of constant weight $\mathrm{W}=\left(\omega_{1}, \omega_{2}, \cdots, \omega_{\mathrm{n}}\right)$.

b. The definition of variable weight set

A set (with $\mathrm{m}$ dimensions) refers to $\mathrm{m}$ mappings of $\omega_{\mathrm{i}}(i=1,2, \cdots, \mathrm{m})$; Represented as:

$\omega_{\mathrm{i}}:[0,1]^{m} \rightarrow[0,1]\left(g_{1}, \cdots, g_{m}\right) \mapsto \omega_{\mathrm{i}}\left(g, \cdots, g_{m}\right)$

Meanwhile, this mapping fit the following axiom:

Normalization: $\sum_{\mathrm{i}=1}^{\mathrm{m}} \omega_{\mathrm{i}}=1$

Continuity: $\omega_{\mathrm{i}}\left(g_{1}, g_{2}, \cdots g_{\mathrm{n}}\right)(i=1,2, \cdots, \mathrm{m})$, each variable is continuous.

Punitive feature: $\omega_{\mathrm{i}}\left(g_{1}, g_{2}, \cdots g_{\mathrm{n}}\right)(i=1,2, \cdots, \mathrm{m}), \omega_{\mathrm{i}}$ is monotonously decreased.

Let $\left\{\omega_{\mathrm{i}}\left(g_{1}, \cdots, g_{m}\right)\right\}(1 \leq j \leq m)$ be a set of $\mathrm{m}$ dimensional variable weight, if $\sum_{\mathrm{m}}^{(\mathrm{g})}(\mathrm{G})=\sum_{\mathrm{m}}^{(\mathrm{g})}\left(\mathrm{g}_{1}, \cdots, \mathrm{g}_{m}\right)=\sum_{j=1}^{m} w_{j}\left(g_{1}, \cdots, g_{m}\right) \bullet g_{j}$, then $\sum_{\mathrm{m}}^{(\mathrm{g})}$ is the variable weight of $\mathrm{m}$ dimensional variables.

c. Empirical formula of variable weight:

Let $\mathrm{W}=\left(\omega_{\mathrm{i}}, \omega_{2} \ldots, \omega_{m}\right)$ be a set of constant weight, suppose the ratio of constant weight $\lambda_{i j}=\frac{\omega_{j}}{\omega_{i}}$, then comes the empirical formula of variable weight:

$$
\eta_{i j}\left(x_{1}, \cdots x_{m}\right)=\frac{\frac{\omega_{1}}{x_{1}}}{\sum_{j=1}^{m} \frac{\omega_{j}}{x_{j}}}
$$

\section{Structuring of Relative Risk-variable Weight Model}

Considering the risk features of municipal PPP Project, this paper upgrades RRM to produce an assessment method suitable for it, which consists of following steps:

a. Structuring of risk assessment index system based on materials collected and documents reviewed [9-12] of PPP's risk analysis. Risk sources, receptors, division of risk units, and the coefficients of exposure-response paths can be determined by adopting the way of semi-structured interview and Delphi method.

b. Structuring of risk assessment model

Step 1 Suppose the number of risk assessment units is $\mathrm{P}$, then the structured set of assessment units is $U=\left\{U_{1}\right.$, $\left.\mathrm{U}_{2}, \ldots, \mathrm{U}_{\mathrm{p}}\right\}$, while assessment unit $\mathrm{U}_{\mathrm{i}}$ refers to the set of risk receptors with the number of $q$, represented as $U_{i}=\left\{U_{i 1}\right.$, $\left.\mathrm{U}_{\mathrm{i} 2}, \ldots, \mathrm{U}_{\mathrm{iq}}\right\}(\mathrm{i}=0,1, \ldots, \mathrm{p})$, by analogy.

Step 2 Measure the influence degree of risk factors by applying the Relative standard table of risk source's strength and frequency level.

TABLE I. RELATIVE STANDARD TABLE OF RISK SOURCE'S STRENGTH AND FREQUENCY LEVEL

\begin{tabular}{|c|c|c|c|}
\hline Strength & Scores & Frequency & Scores \\
\hline High & $(7.5-10)$ & $\begin{array}{c}\text { High } \\
\text { probability }\end{array}$ & $(0.75-1.0)$ \\
\hline Moderate & $(5.0-7.5)$ & $\begin{array}{c}\text { Medium } \\
\text { probability }\end{array}$ & $(0.5-0.75)$ \\
\hline Low & $(2.5-5.0)$ & $\begin{array}{c}\text { Low } \\
\text { probability }\end{array}$ & $(0.25-0.5)$ \\
Very low & $(0-2.5)$ & $\begin{array}{c}\text { Very low } \\
\text { probability }\end{array}$ & $(0-0.25)$ \\
\hline
\end{tabular}

Step 3 Make the set of risk factors $V=\left\{V_{1}, V_{2}, \ldots, V_{k}\right\}$ be relevant to $U_{i}$, then the set of coefficients of exposureresponse paths is $E_{i j}=\left\{e_{i j 1}, e_{i j 2}, \ldots, e_{i j q}\right\}$, indicating the effect of $\mathrm{U}_{\mathrm{ij}}$ on risk factors $\mathrm{V}_{1} \sim \mathrm{V}_{\mathrm{k}} . \mathrm{W}_{\mathrm{ijt}}$ is used to represents the weight of $\mathrm{U}_{\mathrm{ij}}$ affected by the risk factor of t. Its calculation method is shown as Formula (2):

$$
w_{i j t}=\frac{e_{i j t}}{\sum_{T=1}^{q} e_{i j T}}
$$

Step 4 calculate the relative risk index value $U_{i j} R(i, j$ refers to receptor's subscript, is a natural number, more detail is in Figure1.) of receptor $\mathrm{U}_{\mathrm{ij}}$. The calculation method is as follows:

$$
U_{i j} R=\sum_{t=1}^{k} R_{t} \times w_{i j t}
$$


In this formula, $R_{t}$ represents the index value of the receptor's relative risk influence degree affected by $\mathrm{t}(\mathrm{t}=1$, $2, \ldots, \mathrm{k}$ _risk factors. (Definition: $R_{t}=P_{t} \times f_{t} \cdot P_{t}$ represents the index value of harmful level of risk $\mathrm{t}, P_{t}=(1,2, \ldots, 9)$, the smaller the value, the lower the level of harm. $f_{t}$ represents the occurrence probability of risk $\mathrm{t}, f_{t} \in[0,1]$.)

Step 5 set up the set of relative assessment, as is shown in Table 2.

TABLE II. RELATIVE RISK VALUE CORRESPONDING TO RELATIVE RISK LEVEL

\begin{tabular}{|c|c|c|c|c|c|}
\hline & \multicolumn{5}{|c|}{ Relative Risk Value } \\
\cline { 2 - 6 } & $\mathbf{0 . 0 - 2 . 0}$ & $\mathbf{2 . 0 - 4 . 0}$ & $\mathbf{4 . 0}-6.0$ & $\mathbf{6 . 0 - 8 . 0}$ & $\mathbf{8 . 0 - 1 0 . 0}$ \\
\hline $\begin{array}{c}\text { Risk } \\
\text { Level }\end{array}$ & $\begin{array}{c}\text { Very } \\
\text { low }\end{array}$ & Low & Medium & High & $\begin{array}{c}\text { Very } \\
\text { high }\end{array}$ \\
\hline
\end{tabular}

Step 6 set up the set of weight coefficient:

The weight efficient set of the first layer of receptors is $G_{0,0}=\left\{G_{1,0}, G_{2,0}, G_{3,0}\right\}$, the weight of other layers can be get by using set factor analogy. The weight value of each index is obtained by adopting analytic hierarchy process and the results of Delphi questionnaire.

Step 7 multi-level fuzzy comprehensive assessment

Distribution membership function is applied to determine membership vector function. Taking receptor $\mathrm{U}_{1}$ as an example, the matrix of the first level fuzzy risk assessment is $\mathrm{K}_{11}=\mathrm{G}_{11,0}\left(\mathrm{U}_{111} \mathrm{R} \mathrm{U}_{112} \mathrm{R} \mathrm{U}_{113} \mathrm{R} \mathrm{U}_{114} \mathrm{R}\right)^{\mathrm{T}}$, which can be the membership matrix of next level, by analogy, the calculation method the matrix of $\mathrm{U}_{1}$ 's second level fuzzy comprehensive assessment can be concluded.

$$
K_{1}=G_{0,0}\left[\begin{array}{l}
G_{1,0}\left[\begin{array}{c}
K_{11} \\
\cdots \\
K_{1 m}
\end{array}\right] \\
\cdots \\
\cdots \\
G_{n, 0}\left[K_{n m}\right]
\end{array}\right]
$$

By analogy, the general comprehensive assessment set of $\mathrm{K} 2$ and $\mathrm{K} 3$ is $\mathrm{K}_{0}=\mathrm{G}_{0,0}(\mathrm{~K} 1 \mathrm{~K} 2 \mathrm{~K} 3)^{\mathrm{T}}$.

Step 8 amend the assessment results according to the theory of variable weight. Difference analysis should be conducted to elements in Sets $U_{i j} R \& U_{i} R$. If any evaluation factors with distinct gags exist in risk assessment units, their assessment value requires amendment.

\section{APPLICATION EXAMPLES}

\section{A. Project Overview}

The planned total amount of investment is 106.4283 million Yuan, with 46.4283 million Yuan invested in expansion project of A reservoir and 60 million Yuan invested in waterworks and supporting pipe network project. The project capital is 43.2536 million Yuan, among which 12.066 million Yuan are from the government, with the equity ratio of $27.9 \%$, and enterprise investment is 31.1876 million Yuan, with the equity ratio of $72.1 \%$. Bank loan is 64.8804 million Yuan.

After expansion, the A reservoir can provide $300,000 \mathrm{~m}^{3}$ water to the surrounding areas for agricultural irrigation. Besides, the buildup of waterworks will ensure $200,000 \mathrm{~m}^{3}$ of domestic water for surrounding residents.

The construction period of this project is 5 years, and the design working life is 35 years, including 20 years of licensed operation period. The covering area of this project contains three groups of villagers, involving migration of 143 local people.

According to calculations, the proposed water price is lower than the water price of project total cost, but is higher than that of running cost. The project can keep running, but no profit ban be made. Considering the increasing water demand in the project areas and obvious resources water shortage, the current water price cannot really reflect the scarcity of water resources in the regional. There is a good possibility that water price will be raised. In this way, the water revenue of this project will increase, therefore, the project will be profitable.

\section{B. Model Application}

a. Structuring of risk evaluation index system

1. Division of Risk Units and Evaluation Factors

18 biggest factors that influence water conservancy project are proposed as index of risk loss by the method of semi-structured interviews and document review [9-13]. The "political level risk", "market level risk" and "project level risk" are considered as the three risk assessment units respectively.

\section{Selection of risk receptors}

According to the characteristics of the municipal engineering PPP project and performance evaluation factors of engineering project, partnerships and public relations are considered as the second risk receptor of political level risk unit, and the financial risk and the risk of supply and demand are considered as the second risk receptor of market level risk unit. The construction quality, construction cost, contract disputes, product or service quality is considered as the second risk receptor of project level risk unit. The risk evaluation index system is shown in Figure 1.

3. The analysis of exposure-effect. According to the interaction relation of exposure-effect between assessment units, the expose coefficient and effect coefficient are assigned as 0/0.25/0.5/0.75/1. These five numbers correspond, respectively, to inaction, weak indirect effect, indirect effect, strong indirect effect and direct effect. Those effects are empowered through the Delphi method. 


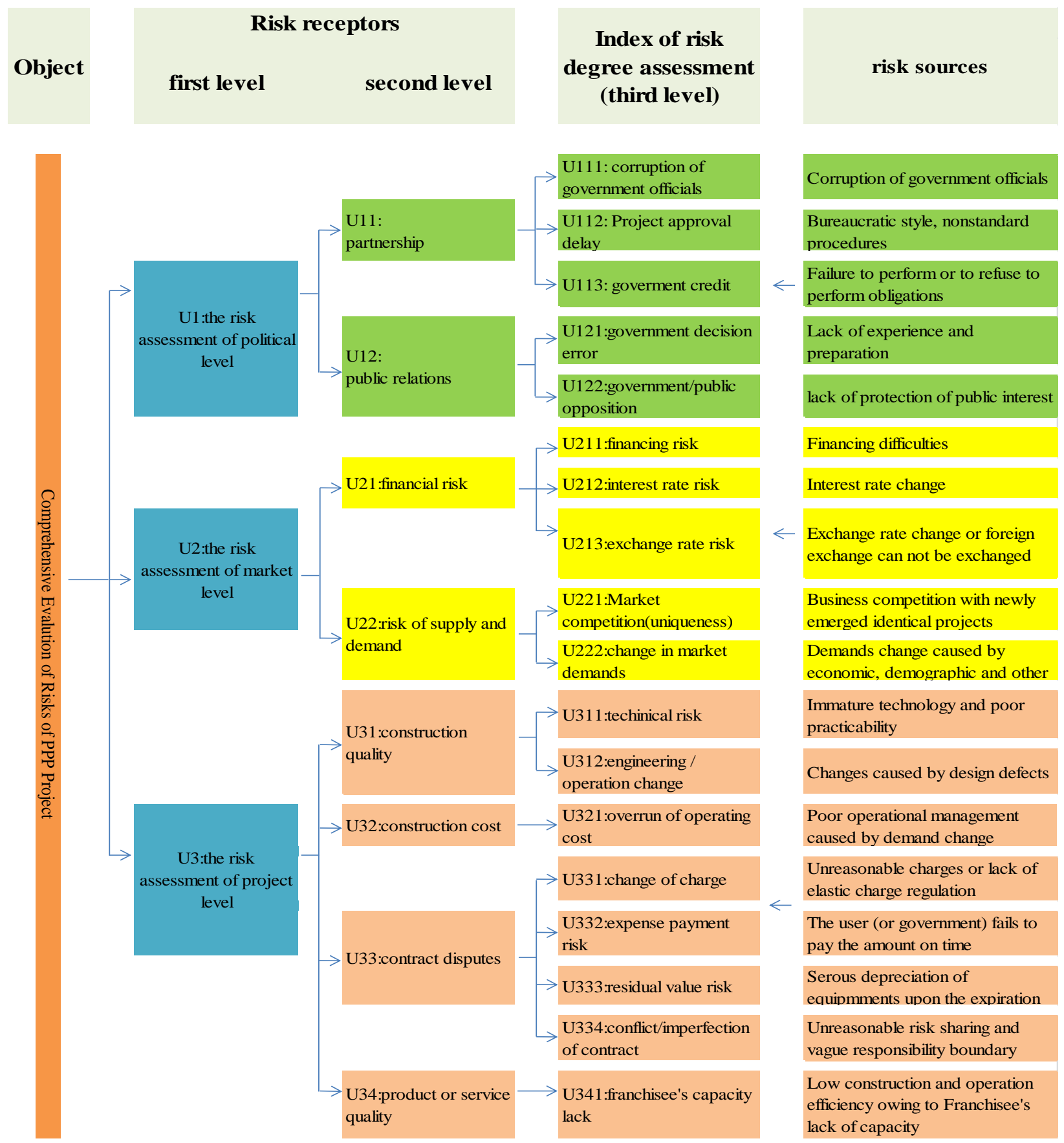

Figure 1. RRM risk evaluation index

b. Application of risk assessment model

Step 1 The structured assessment unit set is represented as $\mathrm{U}=\{$ the risk assessment of political level, the risk assessment of market level, the risk assessment of project level $\}$; The assessment unit $\mathrm{U}_{1}=\{$ partnership, public relations $\}$, the assessment unit $U_{2}=\{$ the financial risk, the risk of supply and demand\}, the assessment unit $\mathrm{U}_{3}=\{$ construction quality, construction cost, contract disputes, product or service quality \}; by that analogy, the lowest evaluation object can be structured as $\mathrm{U}_{\mathrm{ij}}$ $i=(0,1, \ldots, p), j=(0,1, \ldots, q))$, as shown in Figure 1.
Step 2 calculating the influence degree of risk factors $\mathrm{U}_{111} \sim \mathrm{U}_{341}: 2.67,7.30,7.18,3.91,8.62,3.19,0.67,0.36,1.75$, 2.90, 2.67, 3.19, 2.24, 2.93, 5.40, 1.13, 2.90, 1.97 .

Step 3 identifying exposure coefficient set.

Step 4 The index set of the third receptor's relative risk can be calculated, $\mathrm{U}_{111} \mathrm{R} \sim \mathrm{U}_{341} \mathrm{R}=\{3.33,1.73,4.48,5.64$, $6.90,2.12,1.20,0.89,1.98,2.67,2.59,3.27,2.24,3.64,3.57$, $1.66,3.49,1.97\}$.

Step 5 using analytic hierarchy process, combined with questionnaire results of Delphi method, the weight set can 
be identified as $\mathrm{G} 0,0=\mathrm{G}_{0,0}=\{0.41,0.40,0.19\}, \mathrm{G}_{1,0}=\{0.38$, $0.62\}, \mathrm{G}_{2,0}=\{0.42,0.58\}, \mathrm{G}_{3,0}=\{0.24,0.26,0.38,0.12\}$.

Step 6 the comprehensive fuzzy scores of project risk can be calculated, as shown in Table 3 .

Step 7 revising the assessment results according to variable weight.

As can be seen from the Table 3, PPP risk assessment value of municipal works is 3.39 , it belongs to medium risk level as Table 2 shows; But it is worth noting that the assessment value of risk unit of political level is 5.19 in the assessment results of the first risk receptor, which is apparently higher than the assessment value 1.95 of risk unit of market level as well as the assessment value 2.68 of risk unit of project level. In the assessment results of the second risk receptor, the risk assessment value of public relations is much higher than the risk assessment value of "partnership". The reason why the assessment of risk unit of political level is high is that there are relocation population and low credit to the government (The fiscal revenue is limit and the debt paying ability is poor.)

With the context of large differences in the various risk units, the assessment results should be revised according to variable weight. The steps are as follows:

1. Calculating the variable weight risk of receptors of the second political risk unit and revising $\mathrm{U}_{1} \mathrm{R}$ as 6.49 according to Formula (1).

2. By that analogy, calculating the comprehensive variable weight risk and revising it as 4.14 according to Formula (1). At this moment, the overall risk of this project has shifted from low risk to medium risk.

TABLE III. COMPREHENSIVE FUZZY SCORES OF PROJECT RISK

\begin{tabular}{|c|c|c|c|}
\hline $\begin{array}{c}\text { Risk } \\
\text { assessment } \\
\text { value }\end{array}$ & $\begin{array}{l}\text { First } \\
\text { level }\end{array}$ & Second level & Third level \\
\hline \multirow{18}{*}{3.39} & \multirow{5}{*}{5.19} & \multirow{3}{*}{3.44} & 3.33 \\
\hline & & & 1.73 \\
\hline & & & 4.78 \\
\hline & & \multirow{2}{*}{6.35} & 5.64 \\
\hline & & & 6.90 \\
\hline & \multirow{5}{*}{1.95} & \multirow{3}{*}{1.58} & 2.12 \\
\hline & & & 1.20 \\
\hline & & & 0.89 \\
\hline & & \multirow{2}{*}{2.208} & 1.98 \\
\hline & & & 2.67 \\
\hline & \multirow{8}{*}{2.68} & \multirow{2}{*}{3.04} & 2.59 \\
\hline & & & 3.27 \\
\hline & & 2.23 & 2.24 \\
\hline & & \multirow{4}{*}{2.97} & 3.64 \\
\hline & & & 3.57 \\
\hline & & & 1.66 \\
\hline & & & 3.49 \\
\hline & & 1.97 & 1.97 \\
\hline
\end{tabular}

\section{RESEARCH RESULTS AND DISCUSSION}

As a regional risk assessment framework for large scale evaluation, relative risk model can effectively applied in the PPP project risk assessment of municipal works, and can objectively reflect the overall project and risk assessment results of each unit. This model can effectively meet complex assessment requirements of various risk sources and risk impact of municipal works' PPP project, and this model is advantageous to the comparison between impact results of different risk units to find and locate factors or units with biggest effect more clearly.

Since the assessment framework of relative risk model is based on risk assessment of independent unit, and the PPP project of municipal works risk is a systemic problem, the imbalance of assessment results of risk unit may lead to an increase in systemic project risk. Therefore, introducing variable weight can effectively weaken the influence of the imbalance of assessment results of risk unit on the overall assessment results. Constant weights reflect comprehensive superiority degree of factors within the set and the relative importance of each basic goals in decision-making process. However, as for the value of different target value configuration $\psi(f(u))=\left\{\psi_{1}\left(f_{1}(u)\right), \cdots \psi_{n}\left(f_{n}(u)\right)\right\}$, the weight vector $\mathrm{W}=\left(\omega_{1}, \omega_{2}, \cdots, \omega_{\mathrm{n}}\right)$ is fixed.

Therefore, there may be some irrational phenomenon when it comes to practical problems. For example, as for two factors with the same weight: $\psi_{1}(f(u))=$ \{low risk, high risk $\}$ and $\psi_{1}(f(u))=$ \{medium risk, medium risk $\}$, the calculated overall risk value is consistent and approximate. From the perspective of mathematics, in the twodimensional representation, the synthetic function based on weights is a straight line. But in fact, the indifference line of a synthetic function that reflects equilibrium preference should be a curve that towards the ideal point.

\section{REFERENCES}

[1] Thomas, A. V, Kalidindi, S.N., Ananthanaryanan, K. Risk perception analysis of BOT road project participants in India [J]. Construction Management and Economics, 2003, 21(4):393-407.

[2] Akintoye A, Macleod M J. Risk analysis and management in construction. InternationalJournal of Project Management. 1997, 15(1): 31-38

[3] Lyons T, Skitmore M. Project risk management in the Queensland engineeringconstruction industry: a survey. International Journal of Project Management, 2004, 22(1):51-61.

[4] Ye S D, Tiong R L K. The effect of concession period design on completion risk management of BOT projects. Construction Management and Economics, 2003, 21(5): 471-482.

[5] Landis W G, Wiegers J A. Design considerations and a suggested approach for regional and comparative ecological riskassessment [J]. Human and Ecological Risk Assessment, 1997, 3(3):287-297.

[6] WANG P Z. Fuzzy Sets and Theories of Falling Shadows Random Set [M]. Beijing: Beijing Normal University Press, 1985.

[7] Li D Q, Hao F L. Variable weights multifactor decision making based on linguistic factor state values $[\mathrm{J}]$. Systems EngineeringTheory\&Proctice. 2014(01). 
[8] Li H X, Factor spaces and mathamatical frame of Knowledge representation(VIII) [J]. Fuzzy Systems and Mathematics, 1995, 9(3):19.

[9] Chan, A.P.C., Lam, P.T.I., Chan, D.W.M., Cheung, E., Ke, Y.J., 2010. Criticalsuccess factors for PPPs in infrastructure developments: Chinese perspec-tive. J. Constr. Eng. Manag. 136 (5), 484-494.

[10] Chen, C., Hubbard, M., 2012. Power relations and risk allocation in thegovernance of public private partnerships: a case study from China. Polic.Soc. 31, 39-49.
[11] Cheung, E., Chan, A.P.C., 2011. Risk factors of Public-Private Partnershipprojects in China: comparison between the water, power, and transportationsectors. J. Urban Plann. Dev. 137 (4), 409-415.

[12] Ke, Y.J., Wang, S.Q., Chan, A.P.C., Cheung, E., 2011. Understanding the risksin China's PPP projects: ranking of their probability and consequence.engineering. Constr. Archit. Manag. 18 (5), 481-496.

[13] Cheung, E., Chan, A.P.C., Lam, P.T.I., Chan, D.W.M., Ke, Y.J., 2012. Acomparative study of critical success factors for public private partnerships(PPP) between mainland China and the Hong Kong special administrativeregion. Facilities 30 (13/14), 647-666. 